\title{
Research interests arising from photos of nature
}

\author{
Quan-Hoang Vuong \\ AISDL, Vuong \& Associates \\ qvuong.ulb@gmail.com
}

Hanoi, September 3, 2020

There are many different ways and motivations for researchers to come up with research ideas and subsequent implementations.

For me, the mindsponge and serendipity methods work. ${ }^{1,2}$ But they require "inputs." And in several cases, those inputs have the form of photographs of nature and its living things, mainly plants, and animals.

Initially, the idea of taking photos of nature came from reading the National Geographic's call for contributions to its annual National Geographic Photo Contests. ${ }^{3}$ Gradually, the photos taken have sparked a new kind of interest, which finally leads to specific studies. Needless to say, those photos do not have to be very beautiful. They just need to be intriguing. ${ }^{4,5}$ To this end, I tend to have likened the researcher to the traveler, who is "summarizing tourist destinations by mining user-generated travelogues and photos." ${ }^{6}$

Some examples of the photos, taken with the purposes mentioned above in mind, follow. In Photo 1, we can see the shed skin of a cicada left on the bark of an old tree.

In Hanoi, during the late 1970s and early 1980s, a pastime for children at the beginning of summer was to catch cicada juveniles, around 6 P.M. to 9 P.M. We then brought them home, put them inside the mosquito net, and watched them shed the shell. After a beautiful molting moment, and the just-shelled-out cicada looked like a 
fairy. The shells were, supposedly, collected as an input for making some traditional medicine.

Photo 1. The cast exoskeleton of a cicada after molting

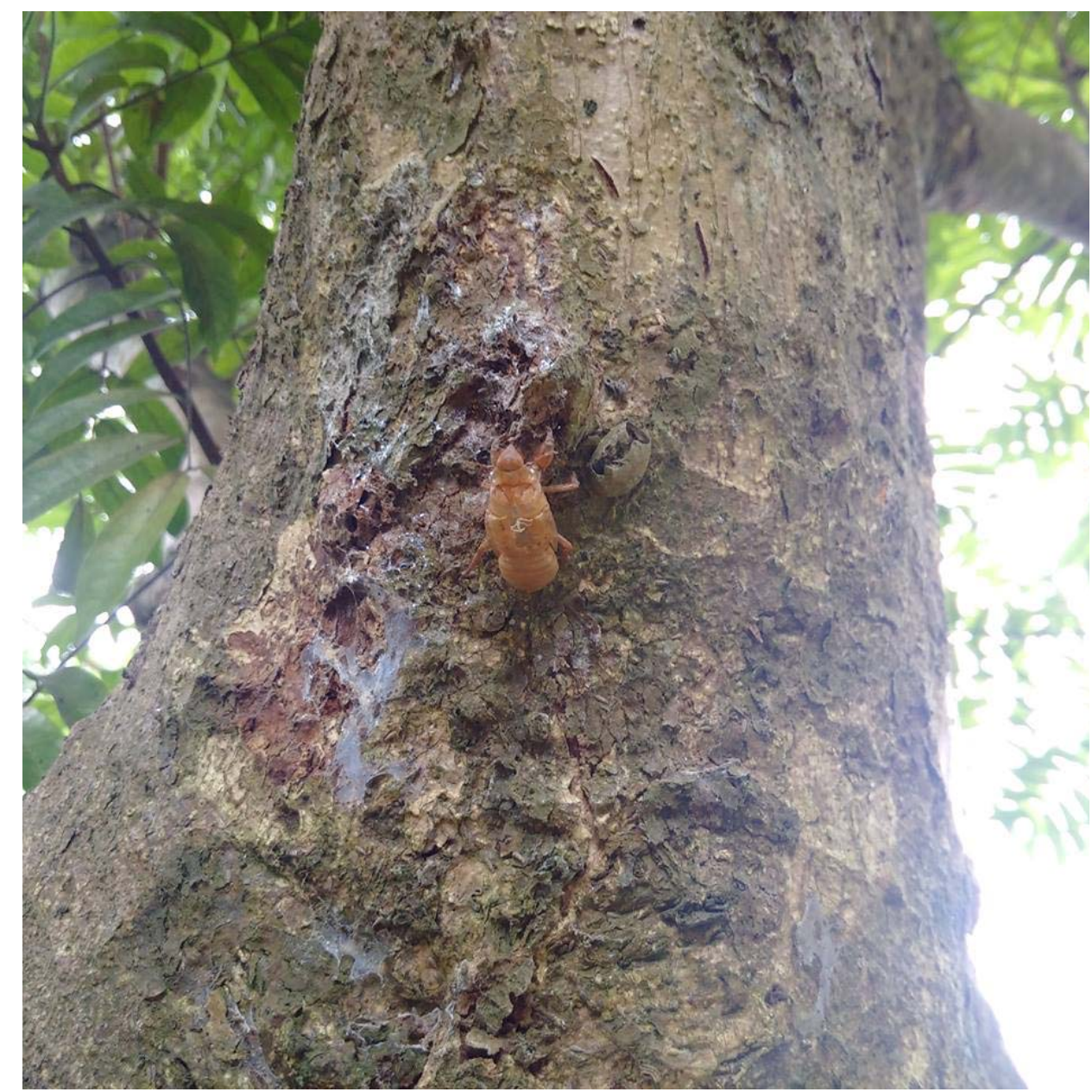

A cicada's shell left on the trunk of a Dracontomelon in my garden, Son Tay, Hanoi. Copyright (C2016 of the author.

Next is the photo of a baby sparrow trying to drink from a wastewater pipe. In fact, there are three of them, but this higher-quality photo shows only one.

Ironically, the photo was taken when there was a huge flood in Hanoi, 2018, summer. 
And this little bird, not yet able to fly fluently. I could take this photo because the birds were able to hop around only. They flew only over a very short span.

\section{Photo 2. A sparrow seeking water}

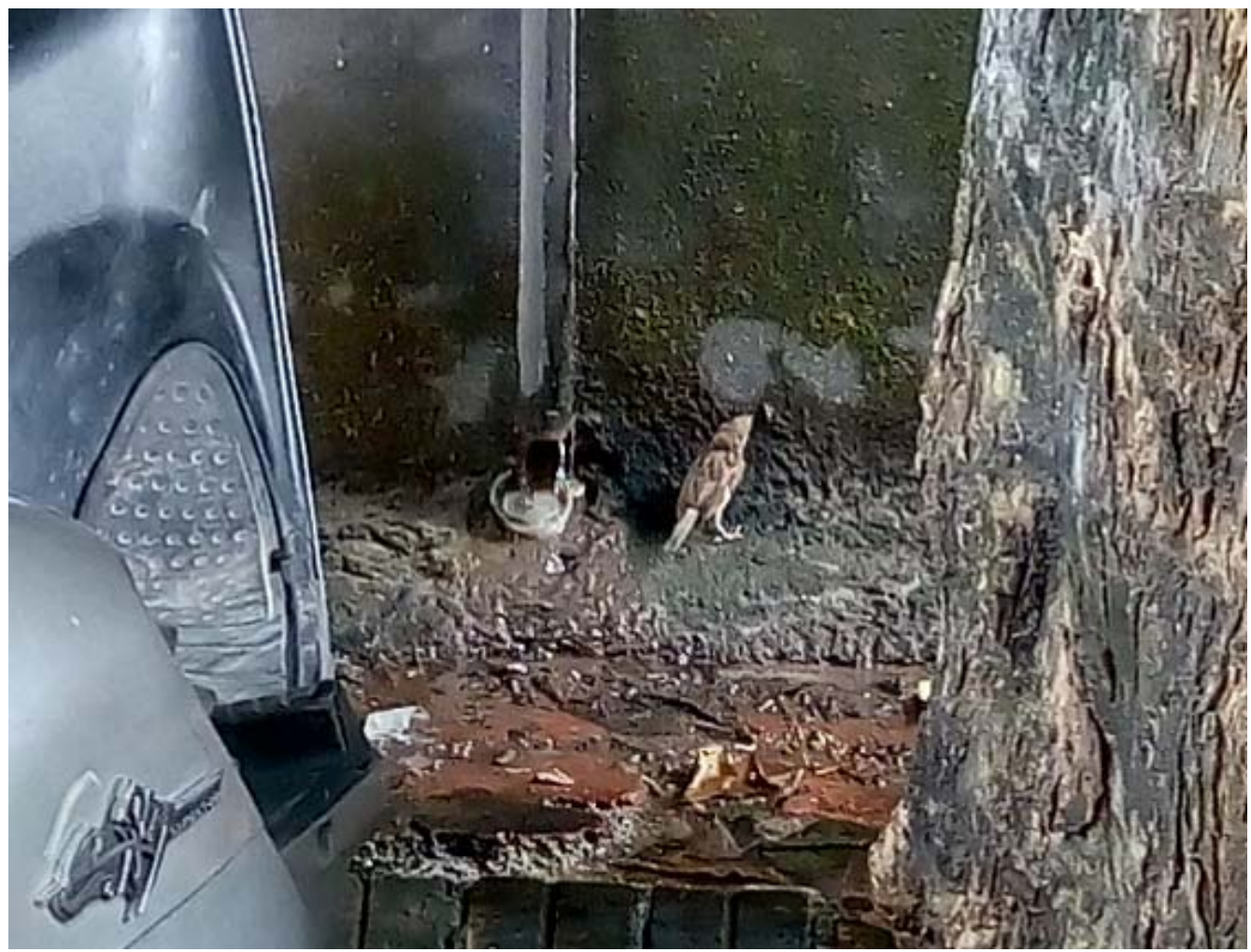

A day-old-chick was desperately seeking drinking water, even when it's wastewater, coming out from an aircon. Copyright (C)2018 of the author.

The photo of the flowerpecker nest, shown in Photo 3, was taken on a Sunday morning. I found it while cleaning the family's cemetery in Bac Giang province, Vietnam. The cemetery had rarely been visited by family members except for the festive seasons.

The parents-birds must have thought that the land had been abandoned. Still, they hid the nest very "thoughtfully" under the wild plants, so people looking at them from afar could not see the nest. Therefore, children playing around the land had left them safe.

From my observation, the time from building the nest, laying eggs to completion of hatching for flowerpeckers is around 8-9 weeks. Thus, I guess the mother-bird would 
soon finish hatching and move on, teaching the chick to fly in about two weeks. So I was lucky to have seen this before they all left the nest.

\section{Photo 3. A bird's nest}

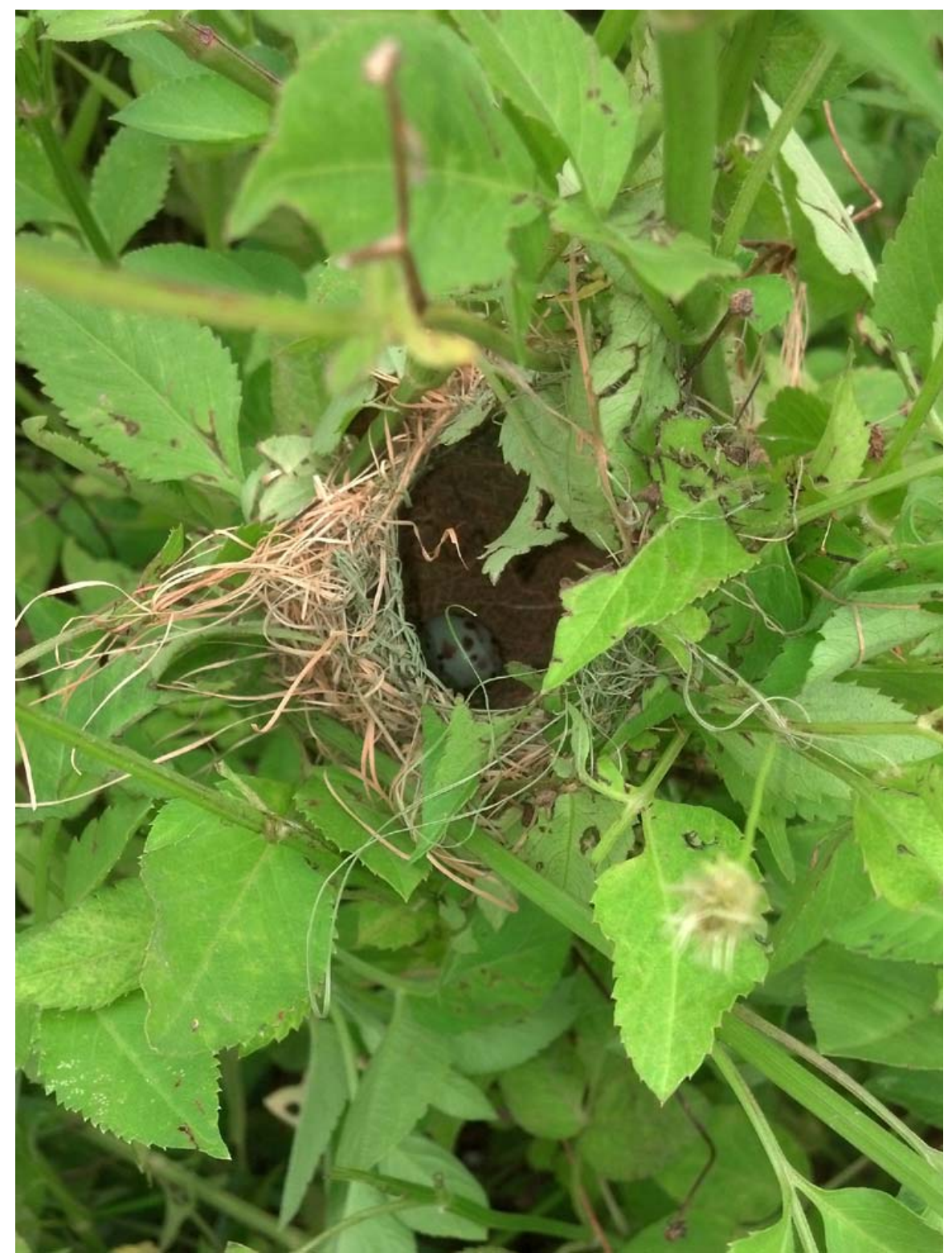

A bird nest in the wilderness, having a flowerpecker egg inside.

Copyright (C)2013 of the author. 
The interests in these photos, among many others, have been with me since I was still a little kid. They continued to be present, at times not very clear, and would one day develop to become real interest in scientific literature, i.e., genuine research publications. ${ }^{7,8,9}$

Naturally, the interests combined with data, analytical techniques and many work hours have turned into manuscripts and publications. ${ }^{10-14}$

Now, my final words are that these living creatures are really beautiful and amazing. Frankly, I could spend many hours looking at them and reflect on their existence. Their beauty brings not just emotion and memory, but also hope and determination in pursuing the good. To this end, research publications represent only a small contribution.

\section{References}

1. Vuong, Q. H., \& Napier, N. K. (2015). Acculturation and global mindsponge: an emerging market perspective. International Journal of Intercultural Relations, 49, 354-367.

2. Napier, N. K., \& Vuong, Q. H. (2013). Serendipity as a strategic advantage?. In: Wilkinson (ed.) Strategic Management in the 21st Century (pp. 175-199). Westport, CT: Praeger.

3. National Geographic. (n.d.). National Geographic Photo Contests. URL: https://www.nationalgeographic.com/contests/

4. Myers, G. (1988). Every picture tells a story: Illustrations in EO Wilson's Sociobiology. Human Studies, 11(2-3), 235-269.

5. Stedman, R., Beckley, T., Wallace, S., \& Ambard, M. (2004). A picture and 1000 words: Using resident-employed photography to understand the attachment to high amenity places. Journal of Leisure Research, 36(4), 580-606.

6. Pang, Y., Hao, Q., Yuan, Y., Hu, T., Cai, R., \& Zhang, L. (2011). Summarizing tourist destinations by mining user-generated travelogues and photos. Computer Vision and Image Understanding, 115(3), 352-363. 
7. Deem, S. L., Karesh, W. B., \& Weisman, W. (2001). Putting theory into practice: wildlife health in conservation. Conservation Biology, 15(5), 1224-1233.

8. Nuwer, R. L. (2018). Poached: Inside the dark world of wildlife trafficking. Hachette, UK.

9. Nogrady, B. (2019). Elusive deer-like animal 'rediscovered' in Vietnam. Nature News (November 11, 2019). DOI: 10.1038/d41586-019-03467-7. Available from: https://www.nature.com/articles/d41586-019-03467-7;

10. Vuong, Q. H. (2019). From children's literature to sustainability science and youth in scientific research. ASEAN Conference for Young Scientists, Phenikaa University, Hanoi, December 2019. Available from: http://dx.doi.org/10.2139/ssrn.3497702

11. Vuong, Q. H., Ho, M. T., Nguyen, H. K. T., \& Nguyen, M. H. (2019). The trilemma of sustainable industrial growth: Evidence from a piloting OECD's Green city. Palgrave Communications, 5(1), 156. DOI: 10.1057/s41599-019-0369-8. Available from: https://www.nature.com/articles/s41599-019-0369-8.

12. Vuong, Q. H., La, V. P., Vuong, T. T., \& Ho, M. T. (2020). Earth Hour in Vietnam: a perspective from the electricity industry. Nature: Behavioural \& Social Sciences (April 21). Available from: https://socialsciences.nature.com/posts/66561-earthhour-in-vietnam-a-perspective-from-the-electricity-industry

13. Vuong, Q. H., La, V. P., Nguyen, T. H. K., Ho, M. T., Vuong, T. T., \& Ho, M. T. (2020). Identifying the moral-practical gaps in corporate social responsibility missions of Vietnamese firms: an event-based analysis of sustainability feasibility. Corporate Social Responsibility and Environmental Management, 27(5): in press.

DOI:10.1002/csr.2029.

14. Vuong, Q. H., Ho, M. T., Nguyen, M. H., Pham, T. H., Ho, H. A., Vuong, T. T., \& La, V. P. (2020). On the environment-destructive probabilistic trends: a perceptual and behavioral study on video game players. arXiv, Preprints No. 2006.09706. Available from: https://arxiv.org/abs/2006.09706. 